\title{
PRINSIP KEBEBASAN BERSERIKAT DALAM SERIKAT BURUH SEBAGAI UPAYA PERLINDUNGAN DAN PENEGAKAN HAK NORMATIF PEKERJA
}

\author{
Oleh \\ Andanti Tyagita*
}

\begin{abstract}
Abstrak
Hubungan kerja terjadi setelah adanya perjanjian antara pengusaha dan pekerja, di mana pekerja menyatakan kesanggupannya untuk bekerja kepada pengusaha dan pengusaha menyatakan kesanggupannya untuk membayar upah pekerja. Namun dalam hubungan kerja terdapat kecenderungan akan adanya ketidakseimbangan kedudukan antara pekerja dan pengusaha di mana pekerja mempunyai posisi tawar lebih lemah daripada pengusaha. Perjuangan para pekerja untuk menegakkan hak-hak normatif tidak serta merta dapat dilaksanakan, sebab dibutuhkan suatu dukungan nyata dari organisasi sebagai wadah untuk memperkokoh kedudukan pekerja. Hal ini kembali dikaitkan dengan hak fundamental pekerja, yakni salah satunya adalah kebebasan berserikat. Dengan pelaksanaan prinsip kebebasan berserikat, dapat diwujudkan dengan menjadi anggota dalam serikat pekerja. Perwujudan penerapan perlindungan hak-hak normatif pekerja oleh Serikat Buruh adalah melalui pembentukan perjanjian kerja bersama antara Serikat Buruh dengan pengusaha.
\end{abstract}

Kata Kunci: Hukum Perburuhan, Prinsip Kebebasan Berserikat, Hak Berserikat, Serikat Buruh, Perlindungan Hak Normatif Pekerja.

\section{PENDAHULUAN}

Tak dapat dipungkiri, pemenuhan kebutuhan hidup secara maksimal hanya dapat diperoleh dengan bekerja, baik bekerja secara mandiri atau bekerja kepada orang lain. Tuntutan hidup di masa kini membuat kebutuhan masyarakat akan lapangan pekerjaan kian meningkat, sedangkan sebaliknya lapangan pekerjaan yang tersedia tidak dapat memenuhi kuota pencari kerja yang membutuhkannya.
Permasalahan ketenagakerjaan yang mendasar di Indonesia antara lain mengenai jumlah pertumbuhan penduduk yang sulit untuk dikendalikan, penyebaran penduduk yang tidak merata dan hanya terfokus pada tempat-tempat tertentu, tingkat pendidikan masyarakat, dan keterbatasan daya serap tenaga kerja yang diakibatkan kurangnya relevansi dunia pendidikan dengan dunia

\footnotetext{
*Pengamat Hukum, andanti.tyagita@gmail.com
} 
kerja. ${ }^{1}$

Jumlah tenaga kerja di Indonesia, baik yang terdidik maupun berpendidikan rendah atau tidak berpendidikan, tidak seimbang dengan ketersediaan lapangan pekerjaan. Pekerja terdidik dan memiliki keahlian tertentu cukup sulit untuk mendapatkan lapangan kerja yang sesuai dengan keahliannya. Apalagi bagi pekerja tak terdidik dengan keahlian terbatas yang jumlahnya terus bertambah. Sehingga posisi tawar mereka terhadap pengusaha menjadi lebih rendah. Hal itulah yang mengakibatkan ketidakpedulian para pekerja akan hak-hak fundamental yang dimilikinya, yakni salah satunya adalah kebebasan berserikat.

Pekerja secara individual berada dalam posisi lemah dalam memperjuangkan haknya. Dengan pelaksanaan prinsip kebebasan berserikat, dapat diwujudkan dengan menjadi anggota dalam serikat pekerja. Berada dalam serikat pekerja, dapat meningkatkan posisi tawar pekerja.

Pengakuan kebebasan berserikat tercantum dalam Pasal 28E ayat (3) Undangundang Dasar 1945 yakni Setiap orang berhak atas kebebasan berserikat, berkumpul dan mengeluarkan pendapat. Prinsip kebebasan berserikat tidak hanya diatur di dalam konstitusi Indonesia, melainkan juga tercantum dalam Undang- undang Nomor 39 Tahun 1999 tentang Hak Asasi Manusia yang merupakan hak atas kebebasan pribadi yakni dalam Pasal 24 ayat (1) dan (2).

Pekerja merupakan warga negara

1 Hadi Setia Tunggul, Pengantar Hukum Ketenagakerjaan Indonesia, (edisi 2, Harvarindo, 2009), 19-22.
Indonesia yang mempunyai hak, baik sebagai individu atau kelompok masyarakat, untuk berserikat dan mendirikan organisasi sebagai salah satu bentuk perlindungan dan penegakan hak normatif mereka selama hak untuk berserikat tersebut digunakan sejalan dan tidak bertentangan dengan peraturan perundang-undangan.

Prinsip kebebasan berserikat berfungsi sebagai hak dasar bagi pekerja untuk berorganisasi dan membentuk serikat pekerja termasuk dalam lapangan hukum perburuhan. ${ }^{2}$ Peraturanperundang-undangan yang mengatur mengenai prinsip kebebasan berserikat menjadi hukum dasar bagi para pekerja untuk membentuk suatu organisasi pekerja atau biasa disebut Serikat Buruh.

Prinsip kebebasan berserikat ini dilindungi dan diakui oleh peraturan perundang-undangan antara lain adanya pengaturan mengenai pemberian kelonggaran pada pekerja yang menjadi pengurus serikat buruh untuk melakukan kegiatan serikat buruh dalam waktu kerja seperti yang tercantumdalam Pasal 29 ayat (1) Undang-undang Nomor 21 Tahun 2000 tentang Serikat Buruh, berhak mengikuti semua kegiatan seperti musyawarah nasional, rapat kerja dan yang berhubungan dengan kegiatan serikat buruh dan disediakan berbagai fasilitas untuk menunjang kelancaran kegiatan pekerja. ${ }^{3}$

Sebagai suatu prinsip dasar, prinsip kebebasan berserikat tidak dapat berdiri sendiri tanpa adanya pengakuan dari

${ }^{2}$ Bahder Johan Nasution, Hukum Ketenagakerjaan Kebebasan Berserikat bagi Pekerja, (edisi 1, Penerbit Mandar Maju, 2004), 4.

${ }^{3}$ Ibid, 7 
peraturan perundang-undangan. Namun prinsip kebebasan berserikat tersebut adalah termasuk salah satu landasan dalam penegakan hak normatif pekerja.

\section{Ruang Lingkup Prinsip Kebebasan Berserikat}

Terkait dengan prinsip kebebasan berserikat yang dianut oleh serikat buruh, maka terdapat kebebasan yang termasuk dalam prinsip tersebut di mana kebebasankebebasan itu diatur dalam Undang-undang Dasar 1945 namun dibatasi oleh undangundang sehingga tidak saling berbenturan antara kebebasan yang dimiliki setiap individu, sebagai wujud pengakuan hak asasi manusia serta untuk menghormati kepentingan umum dan negara. Dalam prinsip kebebasan berserikat, kebebasan yang termasuk di dalamnya antara lain kebebasan untuk berkumpul dan berpendapat serta berekspresi, kebebasan untuk mendirikan dan bergabung dalam organisasi atau kelompok, serta kebebasan untuk menjalankan fungsi administrasi organisasi atau kelompok, membuat aturan organisasi atau kelompok dan menjalankan kegiatannya.

Kebebasan untuk berkumpul yang diberikan oleh Undang-undang Dasar 1945 dan diatur lebih lanjut dalam peraturan perundang-undangan, berkaitan mengenai perkumpulan yang berhubungan dengan politik maupun non politik, yang 28 dalam hal ini salah satunya adalah perkumpulan pekerja. Kebebasan untuk berkumpul dimiliki baik oleh pekerja yang belum tergabung dalam serikat buruh- dengan alasan perusahaannya belum memiliki sekurang-kurangnya sepuluh pekerja sehingga para pekerja tidak dapat membentuk serikat buruh-atau oleh pekerja yang telah tergabung dalam serikat buruh di perusahaannya.

Kebebasan berkumpul selayaknya diisi dengan kegiatan yang bermanfaat, untuk mengutarakan pendapat maupun untuk membicarakan mengenai persoalan yang berhubungan dengan pekerjaan atau persoalan umum. Dalam Undangundang Dasar 1945, kebebasan berkumpul ditujukan bagi warga negara Indonesia dan warga negara asing, sehingga ruang lingkup pengaturannya lebih luas dibandingkan Undang-undang Dasar 1945 sebelum amandemen.

Sedangkan untuk serikat buruh, hak untuk berkumpul dan menyelenggarakan rapat merupakan hak mendasar yang merupakan aspek penting dari tujuan dibentuknya serikat buruh sebab tanpa adanya kebebasan untuk berkumpul dan menyelenggarakan rapat, pembentukan serikat buruh tidak berartiapa-apa. Namun meskipun kebebasan berkumpul adalah hak mendasar bagi serikat buruh, serikat buruh yang bersangkutan harus tetap memenuhi peraturan perundang-undangan yang mengatur mengenai tata cara berkumpul dan menyelenggarakan rapat. Apabila bertentangan dengan peraturan perundangundangan, maka secara otomatis baik pekerja maupun serikat buruh yang bersangkutan akan dikenai sanksi. 
Pemerintah berfungsi sebagai pihak yang mengawasi kebebasan tersebut, dengan maksud apabila terjadi pelanggaran yang dilakukan oleh pekerjaataupun serikat buruh dalam pelaksanaan kebebasan berkumpul, pemerintah atas dasar peraturan perundang-undangan yang berkewajiban untuk menindak secara tegas pelanggaran tersebut. Tindakan pemerintah tersebut tidak termasuk tindakan yang menghalanghalangi pelaksanaan kegiatan serikat buruh namun lebih kepada tindakan penertiban serta pencegahan pelanggaran lebih lanjut. Oleh karena itu agar dapat dibatasi campur tangan pemerintah dalam kebebasan berkumpul, sebaiknya pekerja atau serika buruh mematuhi dan melaksanakan peraturan perundangundangan yang memuat tata cara pelaksanaan kebebasan berkumpul serta memastikan kebebasannya tersebut tidak mengganggu masyarakat atau ketertiban umum.

Setiap pekerja yang tergabung dalam serikat buruh berhak untuk mengutarakan pendapatnya dengan kalimat yang tidak menyinggung, tidak menghina atau merendahkan pekerja lainnya serta harus menghormati kebebasan berpendapat pekerja lainnya. Sebagaimana tercantum dalam Pasal 28 Undang-undang Dasar 1945, pelaksanaan kebebasan mengeluarkan pendapat adalah dengan cara lisan dan tulisan. Berpendapat secara tulisan dapat diekspresikan dengan melalui pers seperti surat kabar, majalah juga jurnal-jurnal ilmiah, baik yang berhubungan dengan pekerja maupun untuk masyarakat umum.

Sedangkan kebebasan untuk mendirikan organisasi atau kelompok berkaitan erat dengan kebebasan berkumpul dan mengeluarkan pendapat. Agar suatu perkumpulan lebih tertata dan terorganisir, sebaiknya dibentuk suatu wadah yakni organisasi, kelompok 31 atau serikat. Sebagaimana diatur dalam Undang-undang Dasar 1945, kebebasan mendirikan dan bergabung dalam organisasi atau kebebasan berserikatmerupakan hak setiap orang. Penafsiran 'setiap orang' berarti kebebasan tersebut ditujukan tidak hanya kepada warga negara Indonesia saja namun kepada warga negara asing juga.

Sedangkan dalam Konvensi ILO Nomor 87 Tahun 1948 yang telah diratifikasi Indonesiadengan KeputusanPresidenNomor 83 Tahun 1998 menegaskan bahwa pekerja dan pengusaha, tanpa perbedaan apapun, memiliki kebebasan untuk mendirikan atau bergabung dalam organisasi, baik organisasi pekerja maupun pengusaha, atas pilihan sendiri dan tanpa dipengaruhi pihak lain.

Dalam Pasal 8 konvensi tersebut menyatakan bahwa dalam melaksanakan hak-hak dan kebebasan yang diatur dalam konvensi tersebut, pekerja dan pengusaha harus tunduk pada hukum yang berlaku pada negara yang meratifikasi konvensi tersebut, yang dalam hal ini adalah Indonesia maka yang berlaku Undang-undang Dasar 1945 dan peraturan perundang-undangan lainnya.

Kalimat 'tanpa pembedaan apapun' dikaitkan dengan yang tercantum dalam Undang-undang Dasar 1945 yakni 'setiap orang', maka kebebasan berserikat ditujukan 
tanpa adanya diskriminasi jenis kelamin, warna kulit, suku bangsa, kepercayaan, dan kewarganegaraan. Sehingga apabila diartikan, warga negara Indonesia dan warga negara asing — dalam hal ini pekerja asing_dapat pula mendirikan serikat dan bergabung menjadi anggota serikat buruh. Yang menjadi 32 permasalahan adalah apakah peraturan perundang-undangan memperbolehkan pekerja asing untuk mendirikan serikat buruh ataupun bergabung di dalamnya.

Pasal 5 Undang-undang No 21 Tahun 2000 tentang Serikat Buruh menyebutkan bahwa setiap pekerja berhak membentuk dan menjadi anggota serikat buruh. Pekerja adalah setiap orang yang bekerja dan menerima upah atau imbalan dalam bentuk lain. Di dalam Undang-undang No 13 Tahun 2003 tentang Ketenagakerjaan, yang termasuk pekerja tidak hanya pekerja berkewarganegaraan Indonesia saja, melainkan pekerja asing. Dengan demikian menyiratkan bahwa pekerja asing juga dapat membentuk dan menjadi anggota dalam serikat buruh di Indonesia. Namun menurut pendapat penulis, serikat buruh hanya dapat didirikan oleh dan untuk warga negara Indonesia.

Serikat buruh dibentuk dengan berdasarkan Pancasila sebagai dasar negara dan Undang-undang Dasar 1945 sebagai konstitusi Indonesia. Sedangkan pengusaha yang mempekerjakan pekerja asing hanya untuk jabatan tertentu dan waktu kerja 33 tertentu, sehingga untuk pekerjaan dalam waktu tertentu menggunakan perjanjian kerja waktu tertentu, di mana pekerjaannya tidak bersifat tetap. Pekerja asing tetap sebagai warga negara asing, oleh karena itu pekerja asing tidak menggunakan Pancasila dan Undang-undang Dasar 1945 sebagai dasar negara dan konstitusi. Sehingga tidak mungkin pekerja asing dapat membentuk serikat buruh di Indonesia mengingat pekerja asing tidak menggunakan Pancasila dan Undang-undang Dasar 1945.

Bagi pekerja warga negara Indonesia, tidak seorangpun boleh menghalanghalangi mereka untuk mendirikan atau bergabung dengan serikat buruh manapun selama pendirian serikat buruh memenuhi syarat yang ditentukan olehperaturan perundangundangan. Pekerja juga bebas memilih serikat buruh yang ingin diikuti, tanpa adanya pemaksaan dari pihak manapun namun apabila dalam satu perusahaan terdapat lebih dari satu serikat buruh, maka pekerja hanya boleh bergabung pada salah satu serikat buruh dalam perusahaan tersebut dan memberikan pernyataannya.

Kebebasan selanjutnya adalah kebebasan untuk menjalankan fungsi administrasi, membuat aturan atau menjalankan kegiatan organisasi atau kelompok. Eksistensi suatu organisasi atau kelompok tidak akan tampak apabila organisasi tersebut tidak menjalankan kegiatan dan fungsi administrasinya serta tidak membuat aturan pelaksanaan secara baik.

Organisasi terbentuk biasanya karena adanya permasalahan yang timbul serta adanya kesamaan pendapat, visi dan misi dari beberapa orang yang menginginkan 
pencapaian terhadap satu tujuan yang sama. Demikian halnya dengan pembentukan serikat buruh di mana pekerja memiliki tujuan yang sama terhadap suatu hal sehingga timbulkeinginanuntuk membentuk suatu wadah demi menampung aspirasi anggotanya.

Kebebasan menjalankan fungsi administrasi dan kegiatan organisasi dan membuat aturan merupakan hak yang dimiliki oleh serikat pekerja, namun sifatnya terbatas sebab untuk hal-hal tertentu masih diatur oleh peraturan perundangundangan demi melindungi pihak pengusaha maupun pekerja yang tidak tergabung dalam serikat buruh tersebut.

Undang-undang No 21 Tahun 2000 tentang Serikat Buruh memberikan kebebasan mengenai keanggotan serta kepengurusan serikat buruh. Sehingga untuk pemilihan ketua serikat buruh, semua diserahkan kepada anggota, pemerintah tidak campur tangan. Dalam hal sumber dan pertanggungjawaban keungan serta pembentukan anggaran dasar atau anggaran rumah tangga seluruhnya diserahkan kepada serikat buruh.

Namun pemerintah masih membatasi mengenai hal-hal tertentu seperti pengaturan mengenai fungsi-fungsi serta tujuan yang harus dilaksanakan oleh serikat buruh juga hak dan kewajiban yang dimiliki serikat buruh. Serikat buruh wajib didaftarkan dan dicatatkan pada instansi pemerintah yang bertanggung jawab di bidang ketenagakerjaan. Pelaksanaan kegiatan serikat buruh masih berada dalam pengawasan pegawai pengawas ketenagakerjaan dengan tujuan agar pelaksanaan kegiatan serikat buruh tidak melanggar ketentuan perundang-undangan. Disinilah tampak bahwa pemerintah masih membatasi kebebasan tersebut seperti mengatur hingga fungsi dan tujuan serikat buruh.

Sehingga meskipun pemerintah memberikan kebebasan bagi serikat buruh untuk melaksanakan kegiatan administrasi serta membuat aturan serikat buruh, namun batasan-batasan tertentu tidak boleh dilanggar oleh yang bersangkutan agar serikat buruh dianggap sah untuk melaksanakan kegiatannya.

\section{Single Union dan Multi Union dalam Kaitannya dengan Prinsip Kebebasan Berserikat}

Perubahan yang signifikan terjadi pada Serikat Buruh di Indonesia terutama dalam hal kebebasan berserikat yakni sejak diratifikasinya Konvensi ILO No. 87 Tahun 1948 tentang Kebebasan Berserikat dan Perlindungan Hak untuk Berorganisasi, konvensi tersebut diratifikasi pada tanggal 9 Juni1998 melalui Keputusan Presiden No 83 Tahun 1998 dan dua tahun kemudian dibentuk Undangundang No 21 Tahun 2000 tentang Serikat Buruh. Tujuan dari Konvensi ini adalah untuk memberikan jaminan kepada pekerja/buruh dan pengusaha akan kebebasan untuk mendirikan dan menjadi anggota organisasinya, demi kemajuan dan kepastian dari kepentingan-kepentingan pekerjaan mereka, tanpa sedikitpun ada 
keterlibatan negara. ${ }^{4}$

Pada saat sebelum kemerdekaan, Indonesia memiliki lebih dari satu serikat buruh yang kemudian dengan adanya perjuangan Indonesia menuju kemerdekaan, serikat buruh tersebut lebih mengarah kepada politik. Oleh karena itu pada tahun 1969 dibentuklah Majelis Pemusyawaratan Buruh Indonesia (MPBI) di mana terdapat kurang lebih dua puluh satu serikat buruh yang bergabung. Serikat tersebut bertujuan untuk menyatukan dan menyederhanakan serikat-serikat buruh sertasebagai wadah untuk menampung segala saran juga berdialog.

Kemudian pada tahun 1973, terinspirasi oleh MPBI, terbentuklah Federasi Buruh Seluruh Indonesia (FBSI) di mana seluruh serikat buruh dileburkan menjadi satu. FBSI merupakan satu-satunya serikat buruh yang diakui pemerintah Indonesia, yang dikenal dengan istilah Single Union. Single Union suatu model hubungan industrial dimana peran pemerintah sangat dominan dalam menentukan syarat-syarat kerja dan kondisi kerja serta serikat buruh diposisikan sebagai kepanjangan tangan pemerintah. ${ }^{5}$ FBSI kemudian digantikan menjadi Serikat Pekerja Seluruh Indonesia(SPSI). Serikat buruh saat itu kurang menampung aspirasi anggotanya dan lebih dikendalikan oleh pemerintah.

\footnotetext{
${ }^{4}$ Indah Budiarti, Kebebasan Berserikat dan Hak Berorganisasi Buruh, http://unionism.wordpress. com/2008/10/31/kebebasan-berserikat-dan-perlindunganhakberorganisasi/, 10 April 2011

5 Abdul R Budiono, Hukum Perburuhan, (edisi 2, Penerbit Indeks, 2009) 13-14
}

Saat Indonesia menganut Single Union, prinsip kemandirian yang seharusnya ada dalam serikat buruh tidak dapat terpenuhi. Dalam prinsip kemandirian serikat buruh maupun pekerjanya terlepas dari dominasi kekuatan luar seperti pengusaha, pemerintah, pengaruh politik, organisasi agama maupun tokoh-tokoh individual. ${ }^{6}$ Meskipun belum sepenuhnya diterpenuhi, namun prinsip kemandirian diakui pemerintah sekarang ini saat Indonesia menganut Multi Union. Sebagai salah satu contohnya adalah Pasal 28 Undang-undang No 21 Tahun 2000 tentang Serikat Buruh.

Oleh karena Single Union dianggap tidak mencerminkan demokrasi dan terkesan sebagai perpanjangan tangan dari pemerintah, maka mulai bermunculan serikat-serikat buruh. Pemerintah kemudian berupaya untuk menjamin kebebasan berserikat bagi pekerja dengan dibentuknya Undang-undang No 21 Tahun 2000 tentang Serikat Buruh di mana serikat buruh tidak hanya berbentuk tunggalnamun setiap pekerja berhak mendirikan serikat buruh. Model hubungan industrial tersebut adalah Multi Union.

Multi Union memiliki peran yang besar dalam menentukan syarat-syarat kerja dan kondisi kerja terutama dalam perjanjian kerja bersamayang tetap ditentukan berdasarkan musyawarah antara pengusaha dengan serikat buruh.

Namun sebenarnya dalam penentuan syarat-syarat kerja, serikat buruh dan pengusaha masih dikendalikan oleh

${ }^{6}$ Asri Wijayanti, Hukum Ketenagakerjaan Pasca Reformasi, (edisi 7,Penerbit Sinar Grafika, 2009) 85 
pemerintah mengingat pengaturan kewajiban dan hak pekerja juga pengusaha diatur dalam peraturan perundang-undangan dan pembentukan perjanjian kerja bersama tidak boleh bertentangan dengan peraturan perundang-undangan.

Dengan adanya Multi Union sebagai upaya pemerintah untuk menjamin kebebasan pekerja untuk berserikat dan berkumpul, bukan berarti Single Union itu tidak menjamin kebebasan berserikat dan berkumpul. Dalam menjalankan hak dan kebebasannya, setiap orang wajib tunduk pada pembatasan yang ditetapkan oleh undang-undang dengan maksud untuk menjamin pengakuan serta penghormatan atas hak dan kebebasan orang lain dan untuk memenuhi tuntutan yang adil sesuai dengan pertimbangan moral, keagamaan, dan ketertiban umum dalam suatu masyarakat. ${ }^{7}$

\section{Pembentukan Serikat Buruh dalam} kaitannya dengan perlindungan hak normatif Pekera

Pembentukan tujuan serikat buruh sebenarnya masih banyak dipengaruhi oleh pemerintah yakni melalui undangundang. Tujuan didirikannya serikat buruh diatur secara garis besar namun mencakup segalanya dalam Pasal 4 ayat (1) Undangundang No 21 Tahun 2000 yakni serikat buruh bertujuan untuk:

1. Memberikan perlindungan

${ }^{7}$ Mahkamah Konstitusi Republik Indonesia, Naskah Komprehensif Perubahan Undang-undang Dasar Negara Republik Indonesia- Buku VIII (Warga Negara dan Penduduk, Hak Asasi Manusia dan Agama) (Sekretariat Jendral dan Kepaniteraan Mahkamah Konstitusi, 2010) 292
2. Melakukan pembelaan hak dan kepentingan

3. Meningkatkan kesejahteraan yang layak bagi pekerja dan keluarganya

Nampaknyaketigatujuantersebutsangat krusial dan merupakan inti dari didirikannya serikat buruh. Inilah suatu bentuk kebebasan yang masih sangat dipengaruhi oleh pemerintah, meskipun nyatanya kebebasan tersebut tidak dilanggar karena undangundang memang mempunyai wewenang untuk membatasinya. Agar tujuan-tujuan dapat tercapai maka dibutuhkan fungsi pelaksananya yakni:

1. Sebagai pihak dalam pembuatan perjanjian kerja bersama dan penyelesaian hubungan industrial.

2. Sebagai wakil pekerja dalam lembaga kerjasama di bidang ketenagakerjaan sesuai tingkatannya.

3. Sebagai sarana menciptakan hubungan industrial yang harmonis dan berkeadilan

4. Sebagai penyalur aspirasi dalam memperjuangkan hak dan kepentingan anggotanya

5. Sebagai perencana, pelaksana dan penanggung jawab pemogokan kerja.

6. Sebagai wakil pekerja dalam memperjuangkan kepemilikan saham dalam perusahaan.

Satu-satunya pihak yang dapat mewakili pekerja dalam perundingan dan pembentukan perjanjian kerja bersama dengan pengusaha adalah serikat buruh. 
Sehingga di sinilah peran penting serikat buruh muncul. Di dalam perjanjian kerja bersama tercantum klausula yang mendukung kepentingan buruh. ${ }^{8}$ Meskipun di dalam satu perusahan terdapat lebih dari satu serikat buruh, masing-masing serikat buruh tersebut juga berhak menyalurkan aspirasi anggotanya dalam perundingan perjanjian kerja bersama dengan pengusaha. Ketika perundingan, peran aktif masingmasing perwakilan serikat buruh sangat diperlukan demi memperjuangkan tujuan masing-masing.

Namun alangkah baiknya apabila tujuan beberapa serikat buruh dalam perusahaan tersebut sama sehingga dapat diperjuangkan bersama-sama. Serikat buruh dapat berperan sebagai wakil pekerja dalam lembaga kerjasama seperti lembaga kerjasama bipartit, tripartit, serta lembaga yang bersifat tripartit lainnya seperti Dewan Pelatihan Kerja Nasional, Dewan Keselamatan Kerja, dan Dewan Penelitian, di mana serikat buruh bersama lembaga-lembaga tersebut akan membahas mengenai kebijakan yang berkaitan dengan ketenagakerjaan.

Dewan Keselamatan Kerja merupakan organisasi non profit yang beranggotakan unsur-unsur pemerintah, serikat buruh, organisasi pengusaha, organisasi profesi dibidang keselamatan dan kesehatan kerja dan badan-badan lain yang bertujuan untuk sebagai suatu badan pembantu di tingkat nasional ialah memberikan saran-saran dan pertimbangan nasional kepada pemerintah mengenai masalah-masalah dibidang pembinaan keselamatan dan kesehatan

${ }^{8}$ Abdul R Budiono, op.cit, 181 kerja secara nasional. Dewan Keselamatan Kerja menghimpun dan mengolah segala data dan atau permasalahan keselamatan dan kesehatan kerja ditingkat nasional dan provinsiprovinsi yang bersangkutan. ${ }^{9}$

Untuk menciptakanhubunganindustrial yang harmonis dan berkeadilan, harus ada kerjasama antara pengusaha dan serikat buruh. Serikat buruh tidak dapat hanya menuntut pemenuhan hak dan kesejahteraan para anggotanya namun tidak diikuti dengan pelaksanaan kewajiban sebagai pekerja secara seimbang. Dalam setiap hubungan industrial selalu terdapat dua kepentingan yang berbeda yakni kepentingan pekerja dan pengusaha. Peran serikat buruh dalam menciptakan hubungan industrial yang harmonis adalah dengan cara mencari jalan terbaik bagi pemenuhan dua kepentingan tersebut agar tidak ada pihak yang merasa dirugikan.

Serikat buruh berfungsi sebagai tempat bagi pekerja anggota serikat buruh untuk berpendapat, memberikan saran dan mengutarakan keinginannya. Selama keinginan dan pendapat itu kiranya masuk akal dan dapat dipenuhi, serikat buruh wajib menampungnya untuk dijadikan bahan dalam perundingan pembentukan perjanjian kerja bersama. Hanya aspirasi-aspirasi yangmewakili kepentingan bersama yang akan diperjuangkan bukan yang mewakili pekerja secaraindividu.

Serikat buruh sebagai pihak perencana, pelaksana dan penanggung jawab terjadinya

${ }^{9}$ D3KN, Dewan Keselamatan dan Kesehatan Kerja, http://indosafetydirectory.com/dewan-keselamatan-dankesehatan-kerja-nasional-dk3n/, diakses pada 18 Juli 2011 
pemogokankerja.DalamUndang-undangNo 13 Tahun 2003 diatur pula mengenai mogok kerja yang dilaksanakan oleh para pekerja di perusahaan yang tidka memiliki serikat buruh dan dapat menjadi pihak perencana, pelaksana dan penanggung jawab. Namun mayoritas yang bertugas sebagai perencana, pelaksana dan penanggung jawab mogok kerja adalah serikat buruh.

Ketika mengajak pekerja lain atau anggotanya untuk melakukan mogok kerja, tidak boleh adanya pemaksaan, sebab pekerja berhak menolak ikut serta dalam mogok kerja. Selama serikat buruh memenuhi syarat-syarat yang ditetapkan oleh undang-undang sebelum melaksanakan mogok, maka mogok itu akan dianggap sah dan para pekerja yang melakukan mogok tetap mendapatkan upah.

Sedangkan serikat buruh juga berperan serta dalam memperjuangkan kepemilikan saham pekerja pada perusahaan. Pembelian saham perusahaan merupakan hak setiap orang oleh karena itu pekerja sebenarnya dapat membeli saham perusahaan tempatnya bekerja. Terkadang pekerja secara individual tidak mendapatkan perhatian lebih dari pengusaha sehingga dalam memperjuangkan kepemilikan saham dibutuhkan perwakilan pekerja yakni serikat buruh.

\section{Perjanjian Kerja Bersama sebagai salah satu Penerapan Fungsi Serikat Buruh}

Perjanjian kerjadibuatantara pengusaha dan pekerja secara individual. Sedangkan apabila dikaitkan dengan eksistensi Serikat Buruh, perjanjian yang dibuat antara pengusaha dengan Serikat Buruh yang mewakili pekerja secara kolektif bukan disebut perjanjian kerja melainkan disebut perjanjian kerja bersama. Menurut Pasal 1 angka 21 Undang-undang No 13 Tahun 2003 tentang Ketenagakerjaan:

Perjanjian kerja bersama adalah perjanjian yang merupakan hasil perundingan antar serikat pekerja atau beberapa serikat pekerja yangtercatat pada instansi yang bertanggung jawab di bidang ketenagakerjaan dengan pengusaha, atau beberapa pengusaha atau beberapa perkumpulan pengusaha yang memuat syarat-syarat kerja, hak dan kewajiban kedua belah pihak.

Sehingga dapat disimpulkan bahwa perjanjiankerjabersamamemilikiunsurunsur sebagai berikut: hasil perundingan antara serikat pekerja atau beberapa serikat pekerja yang tercatat pada instansi yang bertanggung jawab di bidang bersama harus dibuat antara serikat pekerja atau beberapa serikat pekerja dengan bersama harus dibuat antara serikat pekerja atau beberapa serikat pekerja dengan pengusaha atau perkumpulan pengusaha.

Bagi pihak pekerja, diharuskan adanya kolektivitas dalam pembuatan perjanjian kerja bersama tersebut sebab inti dari perjanjian kerja bersama adalah pihak pekerja tidak membuat perjanjian tersebut secara individual melainkan secara bersama-sama, sehingga keberadaan serikat pekerja sebagai pihak perjanjian kerja bersama adalah mutlak. Sebab salah satu tujuan adanya perjanjian kerja bersama adalah untuk mewakili kepentingan pekerja 
yang dianggap tidak bisa dilaksanakan melalui perjanjian kerja. Namun untuk pihak pengusaha tidak diharuskan adanya kolektivitas tetapi dapat juga berbentuk pengusaha secara individual, atau beberapa pengusaha. ${ }^{10}$

Perjanjian kerja bersama dibuat atas dasar musyawarah atau perundingan antara serikat pekerja dengan pengusaha. Apabila tidak tercapai kesepakatan dalam musyawarah, maka penyelesaian pembentukan perjanjian kerja bersama dilakukan melalui prosedur penyelesaian hubungan industrial. Selama melalui proses penyelesaian hubungan industrial, untuk sementara dapat digunakanperaturan perusahaan atau perjanjian kerja bersama yang masih berlaku agar tidak terjadi kekosongan hukum dalam perusahaan, hingga waktu berlakunya peraturan perusahaan tersebut habis kemudian dapat digantikan dengan perjanjian kerja bersama.

Pembentukan perjanjian kerja selayaknya harus memenuhi syarat-syarat agar perjanjian tersebut dapat diberlakukan. Perjanjian kerja bersama harus dibuat berdasarkan asas kebebasan berkontrak dan tidak boleh adanya paksaan atau tekanan dari pihak manapun. Dalam pembuatan perjanjian kerja bersama harus dilandasi dengan itikad baik, adanya kejujuran serta keterbukaan para pihak.

Perjanjian kerja bersama tidak boleh bertentangan dengan peraturan perundangundangan yang berlaku. Meskipun dalam

${ }^{10}$ F.X Djumialdi, Perjanjian Kerja (edisi 10, Penerbit Sinar Grafika,2010) .73 pembuatan perjanjian menganut asas kebebasan berkontrak namun perjanjian kerja bersama kualitas dan kuantitas isinya tidak boleh lebih rendah dari peraturan perundang-undangan.Olehkarenaituapabila ketentuan dalam perjanjian kerja bersama bertentangan peraturan perundangundangan maka ketentuan yang bertentangan itu saja yang batal demi hukum.

Perjanjian kerja bersama dibentuk atas dasar perundingan dan musyawarah antara serikat buruh dan pengusaha di mana perundingan tersebut harus dilandasi kesukarelaan, itikad baik dari kedua belah pihak dan tanpa adanya paksaan. Di dalam satu perusahaan hanya boleh dibuat dan diberlakukan satu perjanjian kerja bersama. Namun apabila perusahaan tersebut mempunyai cabang maka terdapat induk perjanjian kerja bersama yang berlaku umum untuk semua cabangperusahaan tersebut dan di masing-masing cabang perusahaan dapat dibentuk perjanjian kerja bersama turunan yang disesuaikan kondisi cabang masingmasing.

Perundingan dapat dilaksanakan di tiga pilihan tempat yakni di perusahaan, di kantor serikat buruh dan di tempat lain sesuai kesepakatan keduabelah pihak. Namun untuk biaya perundingan perjanjian kerja bersama ditanggungoleh pengusaha, kecuali disepakati lain oleh kedua belah pihak. Pengaturan ini sebenarnya tidak adil sebab apabila dilihat pembentukan perjanjian kerja bersama adalah untuk mengakomodir kepentingan para pekerja namun untuk biaya perundingan ditanggung oleh pengusaha. Alangkah baiknya apabila 
biaya perundingan dibagi sama rata oleh kedua belah pihak. Sebelum melakukan perundingan, para pihak menyepakati tata tertib perundingan yangmeliputi tujuan pembuatan tata tertib, susunan tim perunding, materi perundingan yakni mengenai isi dari perjanjian kerja bersama, tempat perundingan, tata cara perundingan, cara penyelesaian apabila terjadi kebuntuan perundingan, sahnya perundingan dan biaya perundingan. Perundingan yang berhasil akan menghasilkan perjanjian kerja bersama yang dapat diberlakukan dalam perusahaan.

Perjanjian kerja bersama dapat diubah dengan syarat harus atas kesepakatan kedua belah pihak dan perjanjian kerja bersama yang telah mengalami perubahan merupakan satu kesatuan dengan perjanjian kerja bersama yang masih berlaku. Perjanjian kerja yang dibuat oleh perusahaan tidak boleh bertentangan dengan perjanjian kerja bersama tersebut sebab akibat hukumnya apabila terjadi pertentangan maka perjanjian kerja tersebut batal demi hukum, yang diberlakukan adalah perjanjian kerja bersama.

Meskipun perjanjian kerja bersama bisa langsung diberlakukan sejak ditandatangani oleh kedua belah pihak namun tetap harus didaftarkan diinstansi yang bertanggung jawab di bidang ketenagakerjaan. Maksud pendaftaran perjanjian kerja bersama adalah untuk alat monitoring dan evaluasi pengaturan syarat-syarat kerja yang dilaksanakan di perusahaan serta sebagai rujukan utama apabila terjadi perselisihan dalam pelaksanaan perjanjian kerja bersama. Perjanjian kerja bersama yang telah didaftarkan, harus diberitahukan kepada pekerja dengan cara memperbanyak dan membagikannya pada pekerja dalam rangka transparansi.

\section{Keterkaitan antara Perjanjian Kerja Bersama, Serikat Buruh dan Peraturan Perusahaan}

Perusahaan yang memiliki minimal sepuluh orang pekerja, maka wajib membuat peraturan perusahaan. Peraturan perusahaan digunakan sebagai aturan umum dan pedomanberperilakubagiseluruhpekerjadan pengusaha sehingga tidak ada kesewenangwenangan ataupun diskriminasi. Oleh karena itu suatu peraturan perusahaan sekurang-kurangnya memuat mengenai hak dan kewajiban pengusaha, hak dan kewajiban pekerja, syarat kerja, tata tertib perusahaan, dan jangka waktu berlakunya yakni paling lama dua tahun. Namun apabila dalam perusahaan tersebut sudah terdapat serikat buruh yang menginginkan adanya perjanjian kerja bersama, maka pengusaha wajib membentuk perjanjian kerja bersama, sebagaimana diatur dalam Pasal 111 ayat (4) Undang-undang No 13 Tahun 2003 tentang Ketenagakerjaan:

Selama masa berlakunya peraturan perusahaan, apabila serikat buruh di perusahaan menghendaki perundingan pembuatan perjanjian kerja bersama, maka pengusaha wajib melayani.

Persyaratan pembentukan serikat buruh adalah pekerja dalam perusahaan itu dapat mendirikan serikat buruh apabila 
berjumlah minimal sepuluh orang pekerja. Sehingga apabila dalam perusahaan tersebut telah terbentuk satu serikat buruh maka dapat juga membentuk perjanjian kerja bersama meskipun tidak ada keharusan. Seperti yang tercantum dalam Pasal 111 ayat (4) Undang-undang No 13 Tahun 2003 tentang Ketenagakerjaan tersebut, bahwa perjanjian kerja bersama dibentuk apabila serikat buruh menghendaki. Artinya jika serikat buruh tidak berkeinginan untuk membentuk perjanjian kerja bersama, maka peraturan perusahaan tetap berlaku dalam perusahaan tersebut. Namun jika serikat buruh menginginkan pembentukan perjanjian kerja bersama, pengusaha tidak boleh menolak ajakan perundingan dengan serikat buruh.

Dalam perusahaan hanya diperbolehkan satu peraturan yang berlaku, peraturan perusahaan sajaatau perjanjiankerjabersama saja. Ketika perundingan perjanjian kerja bersama tidak juga mencapai kesepakatan, maka yang digunakan adalah peraturan perusahaan tersebut hingga habis jangka waktu berlakunya. Lain halnya apabila dalam perusahaan tersebut telah memiliki perjanjian kerja bersama sebelumnya dan para pihak menginginkan adanya perubahan, maka jika perundingan tidak juga mencapai kesepakatan yang digunakan dalam perusahaan itu adalah perjanjian kerja bersama sebelumnya.

Apabila dalam suatu perusahaan telah memiliki perjanjian kerja bersama, maka peraturan perusahaan tidak berlaku lagi sebab peraturan perusahaan dibuat secara sepihak oleh pengusaha dan tidak dapat dipersengketakan oleh pekerja, hak pekerja yang dimuat dalam peraturan perusahaan tidak mendetail seperti yang dibuat dalam perjanjian kerja sebab dalam pembentukannya pekerja hanya sebatas memberikan saran dan pertimbangan saja. Peraturan perusahaan dapat kembali diberlakukan jika dalam perusahaan tersebut tidak ada lagi serikat buruh, misalnya serikat buruh tersebut telah bubar.

Perjanjian kerja bersama masih boleh berlaku hingga jangka waktunya habis kemudian digantikan kembali oleh peraturan perusahaan karena tidak ada lagi serikat buruh, dengan kriteriabahwa ketentuan dalam peraturan perusahaan yang menggantikan perjanjian kerja bersama tidak boleh lebih rendah dari apa yang diatur dalam perjanjian kerja bersama.

Sehingga perjanjian kerja bersama merupakan bentuk perwujudan partisipasi langsung pekerja yang diwakili oleh serikat buruh dalam membuat peraturan yang dapat digunakan dalam pelaksanaan pekerjaannya yang sebelumnya harus melalui tahapan perundingan bersama pengusaha. Peraturan perusahaan adalah peraturan yang digunakan dalam pelaksanaan pekerjaan apabila belum atau tidak terbentuk perjanjian kerja bersama. Peraturan perusahaan dapat digunakan kembali apabila sudah tidak ada lagi serikat buruh dalam perusahaan tersebut dan perjanjian kerja bersama sudah habis jangka waktunya. 


\section{Kesimpulan}

Kebebasan yang mendasari prinsip kebebasan berserikat adalah kebebasan untuk berkumpul dan berpendapat serta berekspresi,kebebasanuntukmendirikandan bergabung dalam organisasi atau kelompok, serta kebebasan untuk menjalankan fungsi administrasi organisasi atau kelompok, membuat aturan organisasi atau kelompok dan menjalankan kegiatannya, di mana kebebasan-kebebasan tersebut tidak bersifat mutlak karena dibatasi oleh peraturan perundang-undangan.

Prinsip kebebasan berserikat diaplikasikan melalui serikat buruh. Terdapat dua model serikat buruh dalam hubungan industrial yang dianut oleh Indonesia sebelum dan sesudah Undang-undang No 21 Tahun 2000 yakni Single Union dan Multi Union. Multi Union lebih mencerminkan prinsip kebebasan berserikat sebab dalam satu perusahaan diperbolehkan memiliki lebih dari satu serikat buruh, berbeda dengan Single Union di mana di Indonesia hanya terdapat satu serikat buruh yang mewakili seluruh pekerja. Namun bukan berarti keberadaan Single Union tidak melanggar kebebasan berserikat sebab undang-undang yang membatasi kebebasan tersebut.

Serikat buruh mempunyai tujuan utama yakni memperjuangkan hak-hak dan kesejahteraan pekerja, terutama pekerja yang menjadi anggota serikat buruh tersebut. Hal tersebut dilakukan dengan adanya perjanjian kerja bersama yang dibuat oleh serikat buruh dan pengusaha, yang berisi ketentuan yang tidak hanya menguntungkan pihak pengusaha saja namun juga menguntungkan pihak pekerja. Apabila terjadi pelanggaran hak normatif yang dilakukan oleh pengusaha, serikat buruh dapat bertindak sebagai wakil pekerja dalam menyelesaikan perselisihan tersebut.

\section{DAFTAR BACAAN}

\section{BUKU:}

Asikin, Zainal, Dasar-dasar Hukum Perburuhan, Raja Grafindo Persada, Jakarta, 2002

Badrulzaman, Mariam Darus, Kompilasi Hukum Perikatan, Penerbit Citra Aditya Bakti, Bandung, 2001

Budiono, Abdul. R, Hukum Perburuhan, Penerbit Indeks, Jakarta, 2009

Gultom, Sri Subiandini, Aspek Hukum Hubungan Industrial, Penerbit Inti Prima, Jakarta, 2008

Djumialdi, F.X, Perjanjian Kerja, Penerbit Sinar Grafika, Jakarta, 2010

KantorPerburuhan Internasional, Kebebasan Berserikat, Kantor Perburuhan Internasional, Jakarta, 2006

Khakim, Abdul, Dasar-dasar Hukum Ketenagakerjaan di Indonesia, Penerbit Citra Adhitya Bakti, Bandung, 2009

Mahkamah Konstitusi Republik Indonesia, Naskah Komprehensif Perubahan Undang-undang Dasar Negara Republik Indonesia- Buku VIII (Warga Negara dan Penduduk, Hak Asasi Manusia dan Agama), Sekretariat Jendral dan Kepaniteraan Mahkamah Konstitusi, Jakarta, 2010

Marzuki, Peter Mahmud, Penelitian Hukum, Prenada Media Grup, Jakarta, 2008 
Nasution, Bahder Johan, Hukum Ketenagakerjaan Kebebasan Berserikat bagi Pekerja, Penerbit Mandar Maju, Bandung, 2004

Ramli, Lanny, Hukum Ketenagakerjaan, Airlangga University Press, Surabaya, 2008

Sutedi, Adrian, Hukum Perburuhan, Penerbit Sinar Grafika, Jakarta, 2009

Tjandra, Surya et.al, Kompilasi Putusan Pengadilan Hubungan Industrial Terseleksi 2006-2007, Trade Union Rights Centre, Jakarta, 2007

Tunggul, Hadi Setia, Pengantar Hukum Ketenagakerjaan Indonesia, Harvarindo, Jakarta, 2009

Wijayanti, Asri, Hukum Ketenagakerjaan Pasca Reformasi, Penerbit Sinar Grafika, Jakarta, 2009

, Fungsi Serikat Pekerja
dalam Peningkatan Hubungan
Industrial, Abstraksi Makalah

\section{PERATURAN PERUNDANG- UNDANGAN:}

Pemerintah Republik Indonesia, UndangUndang Dasar 1945

Kitab Undang-undang Hukum Perdata (Burgerlijk Wetboek)

Pemerintah Republik Indonesia, Undangundang Nomor 18 Tahun 1956 tentang Ratifikasi Konvensi ILO Nomor 98 Tahun 1949 mengenai Berlakunya Dasar-dasar Hak untuk Berorganisasi dan untuk Berunding Bersama

39 Tahun 1999 tentang Hak Asasi Manusia
Undang-Undang No 13

tahun 2003 tentang Ketenagakerjaan , Undang-Undang No 21 tahun 2000 tentang Serikat Buruh

Nomor 83 Tahun 1998 $r$ tentang
Pengesahan Konvensi ILO Nomor
87 mengenai Kebebasan Berserikat
dan Perlindungan Hak untuk
Berorganisasi
Keputusan Menteri Tenaga Kerja dan Transmigrasi No.KEP. 232/ MEN/2003 tentang Akibat Hukum Mogok Kerja yang Tidak Sah

, Keputusan Menteri Tenaga Kerja dan Transmigrasi No.KEP. 48/MEN/IV/2004 tentang Tata Cara Pembuatan Perjanjian Kerja Bersama

, Keputusan Menteri Tenaga Kerja dan Transmigrasi No.KEP. 51/MEN/VI/2004 tentang Istirahat Panjang pada Perusahaan Tertentu

, Keputusan Menteri Tenaga Kerja dan Transmigrasi No.KEP. 102/ MEN/VI/2004 tentang Waktu Kerja Lembur dan Upah Kerja Lembu

Surat Edaran Dirjen Bina Hubungan Ketenagakerjaan dan Pengawasan Norma Kerja No SE02/M/BW/1987

Deklarasi Universal Hak-hak Asasi Manusia Tahun 1948

Kovenan Internasional tentang Hak-hak Sipil dan Politik 1966

Kovenan Internasional tentang Hak-hak Ekonomi, Sosial dan Budaya 1966 


\section{INTERNET:}

Budiarti, Indah, Kebebasan Berserikat dan Hak Berorganisasi Buruh, diunduh dari http://unionism.wordpress. com $/ 2008 / 10 / 31 /$ kebebasanberserikat-dan-perlindungan-hakberorganisasi/, pada tanggal 10 April 2011

D3KN, Dewan Keselamatan dan Kesehatan Kerja, diunduh dari http:// indosafetydirectory.com/dewankeselamatan-dan-kesehatan-kerjanasional-dk3n/, pada tanggal 18 Juli 2011
Hamzah, Ahmad R, Hak Mogok, diunduh dari http://achmadrhamzah. wordpress.com/2010/08/24/, pada tanggal 25 April 2011

Supriyanto, Bambang, Hak Normatif Karyawan, diunduh dari http://www. portalhr.com/klinikhr.html, pada tanggal 1 Mei 2011

Uwiyono, Aloysius, Dinamika Ketentuan Hukum tentang Pesangon, diunduh dari http://m.inilah.com/read/ detail/69/dinamika-ketentuanhukum-tentang-pesangon/, pada tanggal 13 Juli 2011 